\title{
Hydration of the lower stratosphere by ice crystal geysers over land convective systems
}

\author{
S. Khaykin ${ }^{1}$, J.-P. Pommereau ${ }^{2}$, L. Korshunov ${ }^{1}$, V. Yushkov ${ }^{1}$, J. Nielsen ${ }^{3}$, N. Larsen ${ }^{3}$, T. Christensen ${ }^{3}$, A. Garnier ${ }^{2}$, \\ A. Lukyanov ${ }^{1}$, and E. Williams ${ }^{4}$ \\ ${ }^{1}$ Central Aerological Observatory of Roshydromet 3, Pervomayskaya str. Dolgoprudny, Moscow region 141700, \\ Russian Federation, Russia \\ ${ }^{2}$ Service d'Aeronomie, CNRS, University of Versailles St Quentin, BP 3, Verrières le Buisson 91371, France \\ ${ }^{3}$ Danish Meteorological Institute, Lyngbyvej 100, 2100 Copenhagen, Denmark \\ ${ }^{4}$ Dept. of Civil \& Environmental Engineering, Massachusetts Institute of Technology, 77 Massachusetts Ave., \\ Cambridge, MA 02139-4307, USA
}

Received: 24 June 2008 - Published in Atmos. Chem. Phys. Discuss.: 14 August 2008

Revised: 16 December 2008 - Accepted: 20 March 2009 - Published: 27 March 2009

\begin{abstract}
The possible impact of deep convective overshooting over land has been explored by six simultaneous soundings of water vapour, particles and ozone in the lower stratosphere next to Mesoscale Convective Systems (MCSs) during the monsoon season over West Africa in Niamey, Niger in August 2006. The water vapour measurements were carried out using a fast response FLASH-B Lyman-alpha hygrometer. The high vertical resolution observations of the instrument show the presence of accumulation of enhanced water vapour layers between the tropopause at $370 \mathrm{~K}$ and the $420 \mathrm{~K}$ level. Most of these moist layers are shown connected with overshooting events occurring upwind as identified from satellite IR images over which the air mass probed by the sondes passed during the three previous days. In the case of a local overshoot identified by echo top turrets above the tropopause by the MIT C-band radar also in Niamey, tight coincidence was found between enhanced water vapour, ice crystal and ozone dip layers indicative of fast uplift of tropospheric air across the tropopause. The water vapour mixing ratio in the enriched layers exceeds frequently by $1-3$ ppmv the average 6 ppmv saturation ratio at the tropopause and by up to 7 ppmv in the extreme case of local storm in coincidence with the presence of ice crystals. The presence of such layers strongly suggests hydration of the lower stratosphere by geyser-like injection of ice particles over overshooting turrets. The pile-like increase of water vapour up to $19 \mathrm{~km}$ seen by the high-resolution hygrometer during the season of maximum temperature of the tropopause, suggests that the above
\end{abstract}

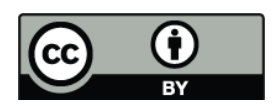

Correspondence to: S. Khaykin (sehamic@yandex.ru) hydration mechanism may contribute to the summer maximum moisture in the lower stratosphere. If this interpretation is correct, hydration by ice geysers across the tropopause might be an important contributor to the stratospheric water vapour budget.

\section{Introduction}

Water vapour is a key player in stratospheric climate and chemistry. It is the most important greenhouse gas controlling partly the temperature of the stratosphere and upper troposphere (Forster and Shine, 2002), as well as a source of hydroxyl radicals and polar stratospheric clouds involved in ozone depletion (Solomon et al., 1986). Its concentration was reported to have increased above Northern America by 5-10\% per decade at all levels between $15-26 \mathrm{~km}$ over the period 1980-2000 (Oltmans et al., 2000; Rosenlof et al., 2001), whilst a cooling of the lower stratosphere of $0.5 \mathrm{~K}$ per decade was reported between 1979-2005 (WMO, 2007), now followed by a levelling off of both parameters since 2001 (Randel et al., 2006). Since troposphere-stratosphere exchange is known to take place primarily in the tropics (Brewer, 1949; Holton et al., 1995), these changes are generally attributed to changes in the vertical transport in the tropical upper troposphere-lower stratosphere (UT-LS). However, the mechanism controlling the amount of water vapour entering the lower stratosphere is still debated. Indeed, whatever is the mechanism of transport invoked - slow radiative ascent, synoptic uplift, or convective overshooting (Sherwood and Dessler, 2000 and references therein) the amount of water vapour transported is generally assumed to be limited by the minimum temperature of the tropopause resulting in the

Published by Copernicus Publications on behalf of the European Geosciences Union. 
dehydration of air entering the lower stratosphere (e.g. WMO 2007). If this mechanism is correct, the observed cooling of the tropopause by $0.5 \mathrm{~K}$ per decade since 1979 (Seidel et al., 2001; WMO, 2007), should have resulted in a dryer stratosphere and not the opposite, casting some doubt on the currently accepted process.

Although a number of satellite observations of water vapour in the stratosphere are available, most of them are of limited use in the Tropical Transition Layer (TTL) between $14-20 \mathrm{~km}$ because of systematic biases, poor precision, frequent presence of clouds, but particularly because of their broad $3-5 \mathrm{~km}$ vertical resolution in a region of large vertical gradients as shown by Montoux et al. (2007). As a result most of the information on this layer comes from in situ measurements provided by sondes, balloons and aircraft, all becoming increasingly available (Kley et al., 1982; Kelly et al., 1993; Jensen et al., 2005; Tuck et al., 2004; Vömel et al., 2002; Weinstock et al., 1995; Richard et al., 2006). However, most of them were carried out over oceanic areas providing little information on land regions known to be the preferred location of most intense convective overshooting (Kent et al., 1995 and references therein), and of lightning indicative of stronger updrafts (Vonnegut and Moore, 1958) as confirmed recently by the TRMM (Tropical Rainfall Measuring Mission) radar overshooting precipitation features and the Lightning Imaging Sensor flashes (Liu and Zipser, 2005; Zipser et al., 2006). However after the pioneering total water measurements from the NASA ER-2 aircraft over Panama in 1980 (Kley et al., 1982) and over Panama and Darwin in 1987 (Kelly et al., 1993), it is only recently that new water vapour profiles over continental convective regions have been made available from the HIBISCUS (Pommereau et al., 2007; Durry et al., 2007) and TROCCINOX (Chaboureau et al., 2007; Corti et al., 2008) balloon and high altitude aircraft campaigns in Brazil, and the SCOUT-O3 aircraft deployment in Northern Australia (Vaughan et al., 2008; Schiller et al., 2007, 2008; Corti et al., 2008). Remarkably, they are all reporting enhanced moisture layers above the tropopause over land convective systems, never seen in maritime observations where sub-visual cirrus are frequent but limited at and below the tropopause (Kent et al., 1995).

The presence of moist layers in the lower stratosphere over land convective systems brings us to consideration of a troposphere to stratosphere transport mechanism associated with convective overshooting, which could explain also the higher concentration of long-lived species of tropospheric origin such as $\mathrm{N}_{2} \mathrm{O}$ and $\mathrm{CH}_{4}$ in the TTL over land, particularly over Africa, as reported by Ricaud et al. (2007). As shown by Danielsen (1993), the explosive convection developing over land in the afternoon could lead to strong overshooting of adiabatically cooled air above the cold point tropopause (CPT) into the stratosphere, which could explain the systematic cooling of the lower stratosphere in the afternoon over an intense overshooting area noted by Pommereau and Held (2007). Alternatively, Wang (2004) has proposed another process, but diabatic, of gravity wave breaking for explaining the observation by Fujita (1989) of "geyser cirrus" jumping 3-4 km above the cloud anvil. While of different nature, both processes could explain the presence of ice particles injected or irreversibly mixed into the lower stratosphere. The study of Liu and Zipser (2005), which was based on TRMM radar observations, demonstrated that significant amounts of ice particles are frequently observed in overshoots over land convective systems. However, because the radar was only able to detect large ice particles that would fall out of the lower stratosphere in a short time, they were unable to predict the overall fate of the overshooting ice. Small ice particles not seen by the TRMM radar may remain aloft for a long time eventually evaporating and thus hydrating the lower stratosphere, as opposed to Danielsen (1982) assuming the water vapour to be trapped at the cold point. The injection of ice particles above the CPT up to $18-19 \mathrm{~km}$ over intense land convective systems was confirmed recently by the balloon and aircraft campaigns over Brazil and Northern Australia (Nielsen et al., 2007; Chaboureau et al., 2007; Corti et al., 2008; De Reus et al., 2008). In the case of Brazil these events were successfully reproduced by Cloud Resolving Models (CRM) suggesting a local injection of a few tons of water per second in the lower stratosphere (Chaboureau et al., 2007; Grovesnor et al., 2007). As reported by in-situ aircraft measurements of $\mathrm{H}_{2} \mathrm{O}$ and $\mathrm{HDO}$ (Hanisco et al., 2007), similar events may also occur in the extra tropical stratosphere displaying isotopic water signatures that are characteristic of sublimated ice lofted from the troposphere during convective storms.

Aiming at better exploring this possible mechanism of hydration of the lower stratosphere by convective overshoots, a series of simultaneous water vapour, particle and ozone measurements has been carried out within a SCOUT-AMMA campaign in August 2006 from Niamey $\left(13.6^{\circ} \mathrm{N}, 2.1^{\circ} \mathrm{E}\right.$, Niger) in West Africa, a location of frequent overshooting during the monsoon season according to Liu and Zipser (2005). Indeed, the summer season in the Sahel region is characterized by the existence of big organised storms, commonly known as MCS (Mesoscale Convective Systems), developing due to the confrontation of moist air from the Gulf of Guinea carried by the monsoon and dry air from the Saharan heat low (Mathon et al., 2002). Those MCSs developing initially over East and Central Africa are travelling westwards and their convective activity is strongly modulated by the diurnal cycle with a maximum development around $16 \mathrm{~h}$ local time (e.g. Liu and Zipser, 2005).

Within the SCOUT-AMMA campaign named after the support of the two European SCOUT-O3 (http:// www.ozone-sec.ch.cam.ac.uk/scout_o3/) and AMMA (http: //www.amma-international.org) projects, a number of soundings (29) of various types and larger balloon flights (7) carrying a variety of instruments were performed, moreover in coordination during the first half of the month with high altitude M-55 Geophysica aircraft flights from Ouagadougou 
$\left(12.2^{\circ} \mathrm{N}, 1.5^{\circ} \mathrm{W}\right.$, Burkina-Faso), $400 \mathrm{~km}$ West of Niamey. Among the sonde flights, six of them were carrying integrated packages of water vapour, ozone and particle measuring instruments. They were flown as close as possible to MCSs identified on Meteosat Second Generation (MSG) and MIT C-band radar images (Williams et al., 2009). The instruments flown on each were a FLASH-B Lyman-alpha hygrometer (Yushkov et al., 1998), a backscatter sonde (Rosen and Kjome, 1991), an Electro-Chemical Cell (ECC) ozonesonde and a Vaisala RS-92 meteorological package (pressure, temperature, humidity and GPS 3-D location). The sondes were reaching $30 \mathrm{~km}$ altitude, after which the measurements were continued during the fast descent below a parachute. A possible connection with overshoots upwind was studied by examination of MSG images available every $15 \mathrm{~min}$ along backward trajectories. The presence of overshoots is identified using the method of brightness temperature difference between 6.2 and $10.8 \mu \mathrm{m}$ for detecting the overshoot signatures (Schmetz et al., 1997) and cloud top information provided by the C-band radar operated with continuous 10 -min volume scans.

The organisation of the paper is the following. Section 2 provides a description of the instruments and details of the experiment, whose results are presented in Sect. 3. The impact of overshooting systems on the lower stratospheric water content and the relation between ice particles and water vapour over a local convective system are discussed in Sect. 4, followed by concluding remarks in Sect. 5 .

\section{Experimental set up}

The sondes payload lifted by an Aerostar $1500 \mathrm{~m}^{3}$ plastic balloon, included from top to bottom, a parachute, a backscatter (BKS) sonde, an EnSci Electro Chemical Cell (ECC) ozone sonde, a Vaisala RS-92-SGP PTU radio sonde (H-Humicap), and a FLASH-B hygrometer coupled with Vaisala RS-80 radiosonde at the bottom $55 \mathrm{~m}$ below the balloon, for a total weight of $10 \mathrm{~kg}$ allowing ascent up to $30 \mathrm{~km}$.

The backscatter sonde, constructed at the University of Wyoming (Rosen and Kjome, 1991), is equipped with a xenon flash lamp, giving a collimated horizontal light pulse about once every $7 \mathrm{~s}$. The backscattered light from aerosol and cloud particles is detected by two silicon photodiodes on the sonde, each equipped with filters transmitting in two wavelengths around $480 \mathrm{~nm}$ (blue) and $940 \mathrm{~nm}$ (red channel). The sonde detects the backscattered signal, at an angle about $173^{\circ}$ with respect to the beam forward direction, from an air volume of approximately $1 \mathrm{~m}^{3}$ within a few meters from the instrument. The basic measurement is the backscatter ratio, i.e. the ratio between the total (particulate and molecular) to the molecular volume backscattering coefficients.

The FLASH-B (FLuorescence Advanced Stratospheric Hygrometer for Balloon) instrument is the Lyman-alpha hygrometer developed at the Central Aerological Observatory for balloon-borne water vapour measurements in the upper troposphere and stratosphere (Yushkov et al., 1998, 2001). The instrument is based on the fluorescent method (Kley and Stone, 1978; Bertaux and Delannoy, 1978), which uses the photodissociation of $\mathrm{H}_{2} \mathrm{O}$ molecules at a wavelength $<137 \mathrm{~nm}$ followed by the measurement of the fluorescence of excited $\mathrm{OH}$ radicals. The source of Lyman-alpha radiation $(\lambda=121.6 \mathrm{~nm})$ is a hydrogen discharge lamp, while the detector of $\mathrm{OH}$ fluorescence at $308-316 \mathrm{~nm}$ is a Hamamatsu R647-P photomultiplier run in photon counting mode with a narrow band interference filter selecting the fluorescence spectral region. The intensity of the fluorescent light sensed by the photomultiplier is directly proportional to the water vapour mixing ratio under stratospheric conditions (10$150 \mathrm{hPa}$ ) with small oxygen absorption $(3 \%$ at $50 \mathrm{hPa})$. The $\mathrm{H}_{2} \mathrm{O}$ measurement range is limited to pressures lower than $300-400 \mathrm{hPa}$ due to strong Lyman-alpha absorption in the lower troposphere.

The instrument uses an open optical layout design (Khaplanov et al., 1992), where the optics is looking directly outside. Such arrangement is suitable for nighttime measurements only at solar zenith angle larger than $98^{\circ}$. The co-axial optical layout allows a reduction in the size of the instrument to $106 \times 156 \times 242 \mathrm{~mm}$ for a total weight of about $1 \mathrm{~kg}$ including batteries. The hygrometer is coupled with a Vaisala RS80 radiosonde providing telemetry as well as pressure and temperature measurements.

Each FLASH-B is calibrated in the laboratory before flight. A description of the procedure can be found in Vömel et al. (2007). The detection limit for a 4-s integration time at stratospheric conditions is of the order of $0.1 \mathrm{ppmv}$, while the accuracy is limited by the calibration error. The total uncertainty is less than $10 \%$ at stratospheric mixing ratios greater than 3 ppmv. Accuracy and good performance of the FLASH-B instrument have been confirmed through pointby-point comparisons with the NOAA-CMDL frost point hygrometer during the LAUTLOS-WAVVAP intercomparison campaign (Vömel et al., 2007) showing excellent agreement between both instruments with a mean deviation of $-2.4+/-3.1 \%$ ( 1 standard deviation) for data between 15 and $25 \mathrm{~km}$

While the minimum response time of the FLASH-B is $0.2 \mathrm{~s}$, here we will use the data averaged over $4 \mathrm{~s}$, resulting in a vertical resolution of $20 \mathrm{~m}$ during ascent and $100 \mathrm{~m}$ during the fast descent ( $15 \mathrm{~m} / \mathrm{s}$ around the tropopause) in the stratosphere. The altitude used in this study is that of the GPS and the potential temperature is that calculated from pressure and temperature provided by the Vaisala RS-92 radiosonde.

The flight configuration of FLASH-B, in which the analyzed volume is located beneath the downward looking optics about $24 \mathrm{~mm}$ away from the lens, caused noticeable self-contamination due to water outgassing from the instrument and possibly also from other equipment and the balloon above during the ascent. In contrast, the FLASH-B measurements during the fast descent at the bottom of the flight train 
Table 1. List of soundings $($ Local Time $=\mathrm{UTC}+1)$.

\begin{tabular}{rccc}
\hline Date & $\begin{array}{c}\text { Launch } \\
\text { time, UTC }\end{array}$ & $\begin{array}{c}\text { Time interval } \\
\text { of descent UTC }\end{array}$ & $\begin{array}{c}\text { Float } \\
\text { altitude }(\mathrm{m})\end{array}$ \\
\hline 3 Aug & $18: 40$ & $20: 23-20: 46$ & 29970 \\
5 Aug & $18: 58$ & $20: 40-21: 13$ & 30146 \\
7 Aug & $18: 40$ & $20: 38-21: 16$ & 30978 \\
14 Aug & $19: 47$ & $21: 25-21: 55$ & 29006 \\
21 Aug & $21: 53$ & $23: 44-00: 08$ & 30710 \\
23 Aug & $19: 07$ & $20: 39-21: 13$ & 25987 \\
\hline
\end{tabular}

in undisturbed air are contamination free as shown by the drop of water vapour readings immediately after the burst of balloon. Accordingly, descent data only are used in the following.

\section{Flight results}

The data available are those of the six soundings, all performed in the evening after sunset and downwind or next to MCSs. The details of the six flights are shown in Table 1. The water vapour, backscatter and temperature profiles of each are displayed in Fig. 1 and the average water vapour profile along with the standard deviation are shown in Fig. 2.

On average, the cold point tropopause (CPT) is at $16.5 \mathrm{~km}$ with a mean value of $-79.5^{\circ} \mathrm{C}$ that is a mean saturation mixing ratio of 6 ppmv. But large deviations are observed between the temperature profiles at all altitudes above the lapse rate tropopause at about $15.5 \mathrm{~km}$. The altitude of the cold point varies between $15.6 \mathrm{~km}$ and $16.8 \mathrm{~km}$, with temperatures ranging from $-77.5^{\circ} \mathrm{C}$ to $-81.5^{\circ} \mathrm{C}$, resulting in saturation ratios varying between 4 and 8 ppmv. Such large variability is very similar to that reported by Pommereau and Held (2007) over Brazil during the convective season, shown to be resulting partly from a 1-2 weeks period Kelvin waves forced by transient deep convection, and partly from local impact of convection on the thermal structure of the lower stratosphere following the overshooting of adiabatically cooled air and possibly also gravity waves of various vertical wavelengths. Remarkable here is the lowering of the altitude of the cold point to $15.6 \mathrm{~km}$ and the cooling at all levels up to $18 \mathrm{~km}$ in the case of local convection on 23 August, similar to that observed in Brazil and attributed the uplift of adiabatically cooled air.

The BKS sonde indicates the frequent presence of cloud anvils and cirrus in the upper troposphere sometimes up to the CPT, a permanent layer of aerosols between 19-21 km, and sporadic thin layers of particles between the tropopause and $18 \mathrm{~km}$, particularly enhanced on 23 August. The aerosol layer at $19-21 \mathrm{~km}$ seen also by all other balloon and aircraft particles measuring instruments during the campaign (optical particle counter, UV-Vis solar occultation spectrometer, backscatter diode laser) was made of $0.1 \mu \mathrm{m}$ radius, undepolarizing and thus spherical liquid particles, the characteristics of volcanic aerosols. Also observed by the CALIPSO lidar from the beginning of the satellite operation in June 2006, they are attributed to the eruption of Soufriere Hills in Montserrat Island in the Caribbean on 20 May 2006 (Vernier et al., 2007). The thin particle layers at $17.5-18 \mathrm{~km}$ above the tropopause are very similar to those detected over Brazil by the same backscatter sonde as high as $20.8 \mathrm{~km}$ (Nielsen et al., 2007), and by the Forward Scattering Spectrometer Probe (FSSP-100) on board the M-55 Geophysica aircraft at around $18 \mathrm{~km}$ over Brazil (Chaboureau et al., 2007) as well as by the Multi-wavelength Aerosols laser Scatterometer (MAS) and the Miniature Aerosol Lidar (MAL) onboard the same aircraft over Northern Australia (Corti et al., 2008; De Reus et al., 2008). Since they were seen during the fast descent of the sonde below a parachute they cannot be attributed to particles falling from the balloon. The colour index of the BKS sonde, i.e. the ratio between the aerosol backscatter ratios at $940 \mathrm{~nm}$ and $480 \mathrm{~nm}$, and the depolarized signal of the backscatter diode laser flown on another balloon (F. Cairo, personal communication, 2008) indicate that, in contrast to the volcanic aerosols at $20 \mathrm{~km}$, these particles are non spherical and of a few micron radius, that is of size comparable to that of the 4.6-9.3 $\mu \mathrm{m}$ ice crystals radius reported by the FSSP-100 on the Geophysica in Northern Australia.

The FLASH-B relative humidity $(\mathrm{RH})$ in the troposphere in the 350-150 $\mathrm{hPa}$ range show very good agreement with the Vaisala RS-92 H-Humicap RH (mean difference of $-0.27 \pm 6.15 \% \mathrm{RH})$. At pressure levels larger than $350 \mathrm{hPa}$, FLASH-B is incapable of measuring humidity due to high absorption of Lyman-alpha emission by water vapour and oxygen. In the stratosphere the FLASH-B data, showing good repeatability, are also consistent with the measurements by the fast in situ Lyman-alpha hygrometer (FISH) (Zoger et al., 1999) flown on the high-altitude M55 Geophysica aircraft during the same period from Ouagadougou, displaying a minimum mixing ratio of $4.2 \mathrm{ppmv}$ at $19 \mathrm{~km}$ $(450 \mathrm{~K})$ (Schiller et al., 2007), compared to the $4.4 \mathrm{ppmv}$ seen by FLASH-B at the same level. Compared to the spaceborne EOS AURA MLS observations (version 2.2, monthly averaged profile for August 2006 above West Africa) the FLASH-B stratospheric profiles are high-biased by about 1 ppmv. While the origin of this discrepancy is not clear, we have no reason to question the reliability of FLASH-B calibration as it has been confirmed through direct comparisons with independent measurements by NOAA-CMDL and CFH frost point hygrometers (Vömel et al., 2007; Khaykin et al., 2008).

In the upper troposphere most water vapour profiles show saturation or supersaturation with respect to ice except on 5 August when the CPT temperature was as high as $-77.5^{\circ} \mathrm{C}$ and no clouds were observed by the BKS sonde. The air inside thick cirrus or anvils is always saturated or supersaturated. Supersaturation in cloud-free conditions was observed 

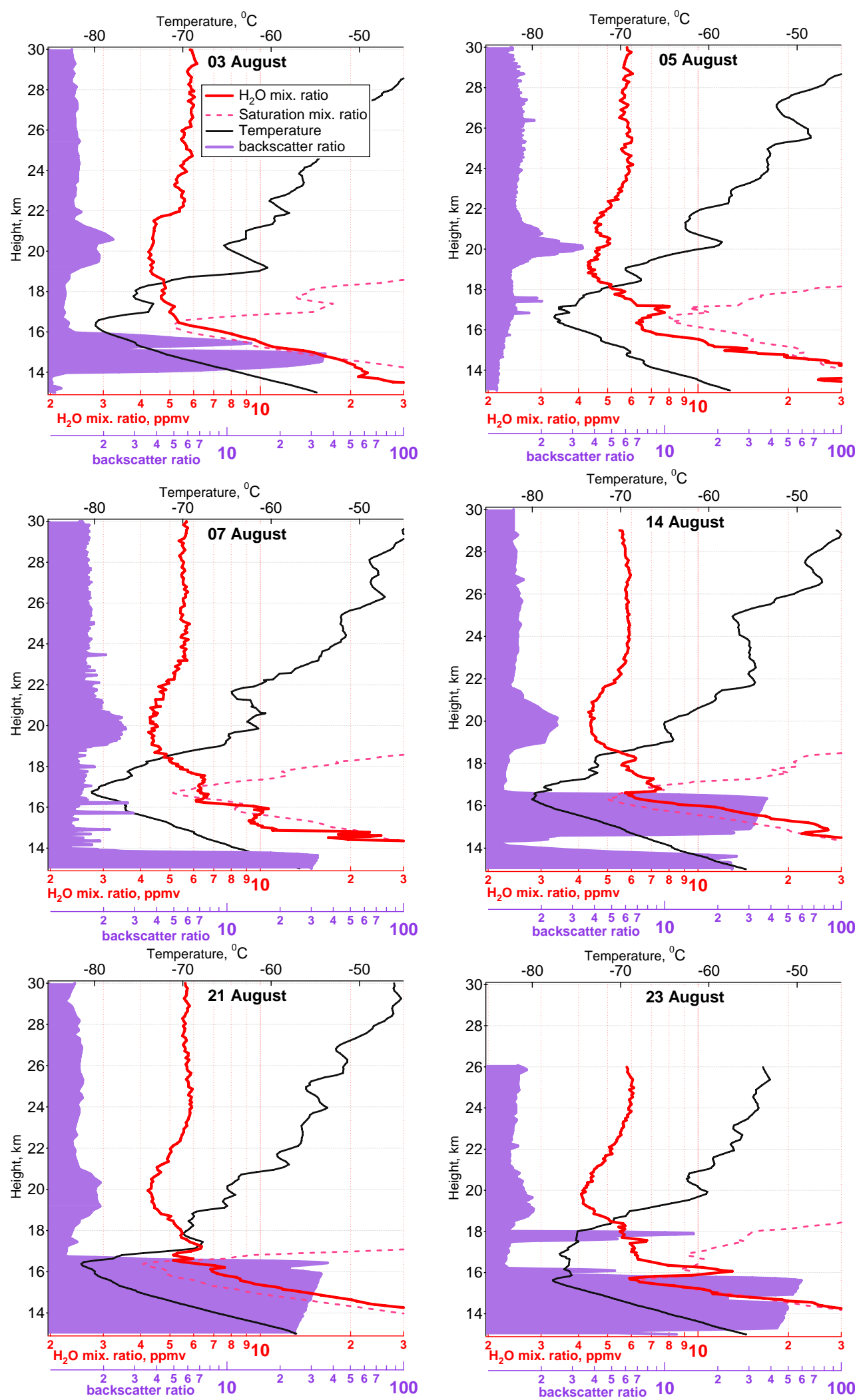

Fig. 1. Results of the six soundings carried out from Niamey, $13.6^{\circ} \mathrm{N}, 2.1^{\circ} \mathrm{E}$, in August 2006: water vapour mixing ratio during descent (red solid), backscatter ratio at $940 \mathrm{~nm}$ during descent, except on ascent on 3 and 5 August (violet filled to zero), temperature (RS80 descent, solid black), and saturation mixing ratio (dashed pink). The dates are shown on each plot. 


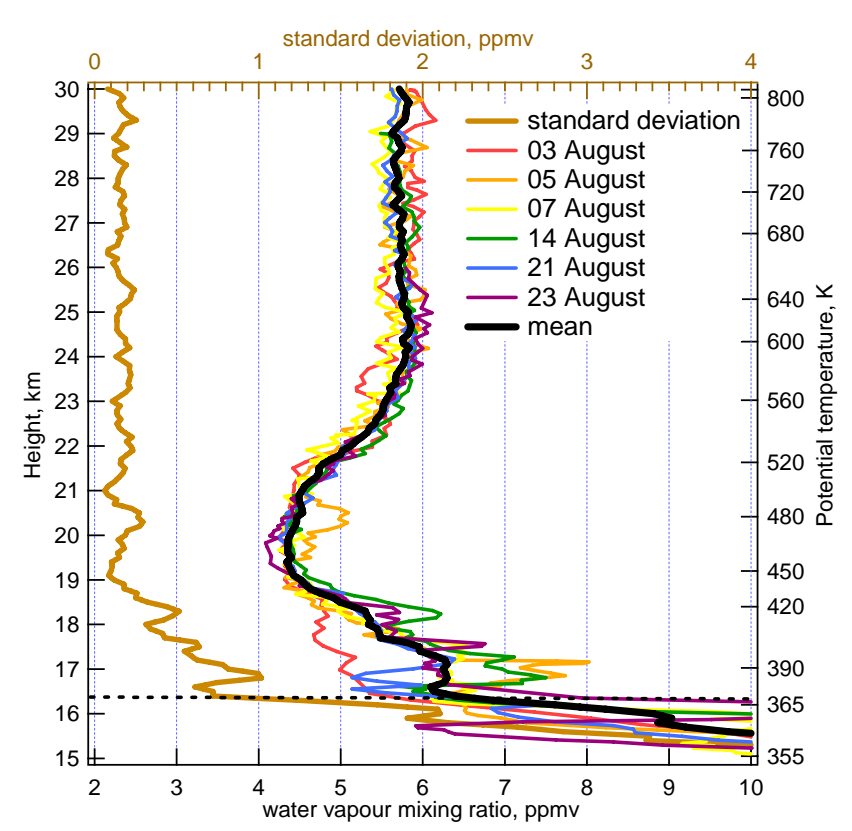

Fig. 2. Individual and mean water vapour profiles of the six soundings (bottom axis) and standard deviation (brown, top axis). The mean tropopause level is shown by black dashed line.

in narrow layers on 3 and 5 August. On 14, 21 and $23 \mathrm{Au}-$ gust cirrus anvil cloud tops reach the CPT level according to the BKS sonde. A maximum saturation ratio as high as $177 \%$ RHi is observed at $15.9 \mathrm{~km}$, a little below the CPT in a cumulonimbus anvil on 14 August. No saturation was observed higher than $600 \mathrm{~m}$ above the CPT. The accuracy of supersaturation ratio measurements is limited only by the errors in temperature and water vapour. The presence of clouds does not affect FLASH-B performance.

A better insight into the vertical structure of water vapour in the stratosphere is provided by Fig. 2 showing the ensemble of descent profiles and the campaign mean calculated from the six soundings along with the standard deviation. The water vapour MR is observed to decrease from an average $6.5 \pm 1 \mathrm{ppmv}$ at the mean CPT to a broad minimum of $4.4 \pm 0.2 \mathrm{ppmv}$ at the hygropause centred at about $20 \mathrm{~km}$ $(475 \mathrm{~K}), 3.5 \mathrm{~km}$ higher than the CPT. Above the minimum the mean mixing ratio is gradually increasing to a maximum of 5.9 ppmv around $24.7 \mathrm{~km}(620 \mathrm{~K})$, above which the mixing ratio is almost constant or slightly decreasing up to $30 \mathrm{~km}$. At these levels where the water vapour is not expected to vary significantly on a short time scale, the standard deviation of the measurements is around $0.15 \mathrm{ppmv}$, consistent with the instrument precision.

Among all profiles, that of 3 August, the first after the beginning of the convective season, is the driest with only a minor enhancement at $17.2 \mathrm{~km}$, whilst all others are displaying multiple layers between the CPT and the hygropause, the largest of 13 ppmv being observed $0.8 \mathrm{~km}$ above the CPT on the last flight close to a local storm on 23 August. Enrichments of $1-3$ ppmv compared to the saturation ratio at the tropopause are observed in the four last flights. But since, with the exception of the case of 23 August, the overshoot possibly responsible for that, may have happened somewhere upwind where the temperature of the tropopause is unknown, the mixing ratio in the enriched layers higher than that of saturation at the tropopause at the location of sonde has little meaning. The extreme 8 ppmv saturation at the tropopause compared to the $6.5 \mathrm{ppmv}$ water vapour at the same level on 5 August is just an indication of sub-saturation during a warm episode. At the opposite, an apparent small increase immediately above a cold point tropopause (e.g. on 7, 14 and 21 August) could be just the signature of condensation at CPT. Most relevant information is that all layers are enriched by $1-3$ ppmv compared to the average $6.5 \mathrm{ppmv}$ mixing ratio at the tropopause. The only exception, where the indication of the sonde temperature at the tropopause is readily relevant is that of the two layers of 13 and 7 ppmv above local convection on 23 August, enriched respectively by 7 and $1 \mathrm{ppmv}$ compared to the 6 ppmv saturation ratio at the tropopause on that day.

The $6.5 \mathrm{ppmv}$ average moisture at the tropopause in $\mathrm{Au}$ gust coincident with the tropopause seasonal temperature maximum, and the high altitude hygropause at $20 \mathrm{~km}$, are consistent with the broad vertical resolution satellite observations during the northern hemisphere summer (e.g. Mote et al., 1996; Schoeberl et al.; 2008). However, the structures shown by the high resolution in-situ measurements, the variability of the concentration compared to the campaign mean, and the fast moisture changes, for example by 3 ppmv at $17 \mathrm{~km}$ between 3 and 5 August at the beginning of the convective season, appear of little consistency with a slow ascent process from the tropopause to $19 \mathrm{~km}$ by radiative heating (Rosenlof et al., 2001), which would take about 6 months during which zonal mixing could be expected. These features would be better compatible with fresh injections of water across the tropopause at altitude up to $18 \mathrm{~km}(420 \mathrm{~K})$. The moisture of the layers frequently higher than the average 6.5 ppmv saturation ratio at the tropopause suggest that the injected water was in the form of ice crystals as those observed by Kelly et al. (1993), Chaboureau et al. (2007), Nielsen et al. (2007), Corti et al. (2008) and De Reus et al. (2008) near deep convective overshooting systems.

\section{Discussion}

A possible mechanism for hydration of the lowermost stratosphere is the sublimation of freshly injected ice crystals by deep convective overshooting, a hypothesis first made by Kley et al. (1982) and then by all above authors. However, the amplitude of the moistening will depend on how much mixing is occurring and therefore on how large the negative buoyancy and thus the subsidence of the injected 
air will be at the end of the overshooting event. CRM simulations (Grovesnor et al., 2007; Chaboureau et al., 2007) are suggesting relatively large mixing resulting in significant water vapour increases after the sublimation of ice particles in the form of "pockets of water vapour anomalies stretched into thin layers with mixing ratio larger than 6 ppmv" (Chaboureau et al., 2007). Although of different nature, the gravity wave breaking process proposed by Wang et al. (2004) for explaining the jumping cirrus after the collapse of the overshooting dome in a region of high turbulence level, should lead also to strong mixing. Whatever is the injection mechanism, the question is thus to know how the water vapour layers, and eventually the particles seen by the BKS, could be related to overshoots occurring upwind or even locally.

\subsection{Relation between water vapour layers and convective overshoot}

The question was addressed by looking at overshoots, which might have occurred upwind along backward trajectories ending at the location of the sonde. The procedure involves calculation of backward trajectories and search for overshoots along them from Meteosat images.

The trajectories are three-day backward 3-dimensional trajectories calculated every $5 \mathrm{~K}$ (approximately $250 \mathrm{~m}$ in the lower stratosphere) in the 350-450 $\mathrm{K}$ range using the TRACAO trajectory model (Lukyanov et al., 2003), based on ECMWF T511 $1^{\circ} \times 1^{\circ}$ operational analyses on pressure levels. The calculations are performed by time steps of $15 \mathrm{~min}$ utes corresponding to the time resolution of MSG satellite images, a product of the SEVIRI (Spinning Enhanced Visible and Infrared Imager) instrument onboard Meteosat-08 (MSG-01). The presence of convective overshoots along the trajectories is identified from MSG images by the brightness temperature difference (BTD) technique (Schmetz et al., 1997). This technique is based on the observation of the difference between cloud top emissions at two wavelengths, $6.2 \mu \mathrm{m}$ and $10.8 \mu \mathrm{m}$, the first being sensitive to the water vapour emission at higher temperature in the lower stratosphere above the cloud in contrast to the adiabatically cooled turret. The method for tracing back the enhanced $\mathrm{H}_{2} \mathrm{O}$ layers to overshoots upwind was implemented in an automated procedure making use of the raw MSG data on brightness temperature at the two wavelengths for calculating BT difference. An overshoot is said to be present when more than a single MSG pixel of $3 \mathrm{~km} \times 3 \mathrm{~km}$ size located within a certain domain centred at the trajectory point has BTD property exceeding the threshold of $3 \mathrm{~K}$. The $3 \mathrm{~K}$ threshold is similar to that used in Chaboureau et al. (2007) and is smaller than the empirical value of $5 \mathrm{~K}$ used by Roca et al. (2002) to analyze deep convection over the Indian Ocean. The uncertainty of trajectory position was accounted for by a proportional increase of the domain radius up to about $200 \mathrm{~km}$ for $48 \mathrm{~h}$ travel time. Overshooting signatures were searched

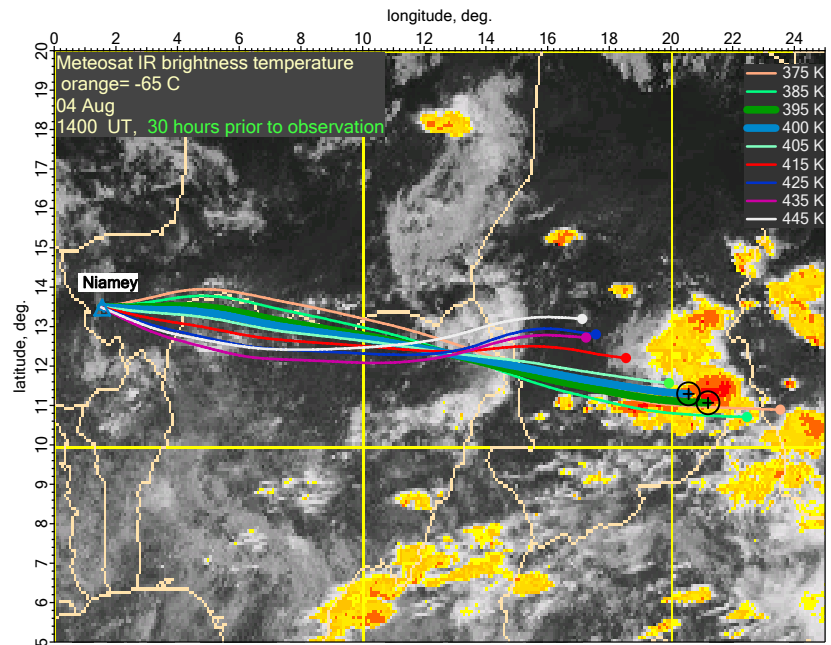

Fig. 3. $30 \mathrm{~h}$ backward trajectories ending between 375 and $445 \mathrm{~K}$ at the sonde location at 20:00 UT on 5 August superimposed on MSG $10.8 \mu \mathrm{m}$ brightness temperature image at 14:00 UT on 4 August. The location of air parcels at each level at the time of the MSG image is indicated by thick dots. The trajectories at $395 \mathrm{~K}$ and $400 \mathrm{~K}$ passing by that time over an MCS are represented by thicker lines and black-circled crosses.

for along each trajectory, while the size of every detected overshoot was roughly estimated by counting the MSG pixels with BTD exceeding $3 \mathrm{~K}$ within the given domain.

Figure 3 shows an example of backward trajectories at different potential temperature levels ending at the sonde location on 5 August at 20:00 UT, superimposed on an MSG BT image on 4 August at 14:00 UT. The two trajectories ending at $395 \mathrm{~K}$ and $400 \mathrm{~K}$ passed over an overshooting MCS $30 \mathrm{~h}$ prior to the sounding. The time when the air mass was passing over an overshooting area and its size were explored for each trajectory. An example of such analysis for $5 \mathrm{Au}-$ gust is shown in Fig. 4. The time at which overshoots were encountered are represented by markers at the potential temperature level where it has been observed, of size proportional to the number of MSG pixels with BTD $>3 \mathrm{~K}$ within the given domain. In this example, three overshoots were detected upwind, a large one of 23 pixels at $390 \mathrm{~K}$ and a smaller one of 12 pixels at $395 \mathrm{~K} 30 \mathrm{~h}$ before the sounding, and another small one of 6 pixels at $410 \mathrm{~K} 48 \mathrm{~h}$ before. The three are corresponding to water vapour layers centred at $17.1 \mathrm{~km}$ $(391 \mathrm{~K})$ and $17.9 \mathrm{~km}(411 \mathrm{~K})$. However, no overshoot could be identified corresponding to the layer at $20.3 \mathrm{~km}(492 \mathrm{~K})$, its possible origin will be discussed below.

The information relevant to all observed water vapour enhanced layers is summarized in Table 2. A connection of water vapour enhancements larger than $0.3 \mathrm{ppmv}$ (three times the detection limit) with an overshoot upwind during the three previous days could be identified for 8 cases out of 10 reported, leaving unexplained the high altitude $0.6 \mathrm{ppmv}$ bump at $492 \mathrm{~K}$ on 5 August and the enhancement of $0.7 \mathrm{ppmv}$ 


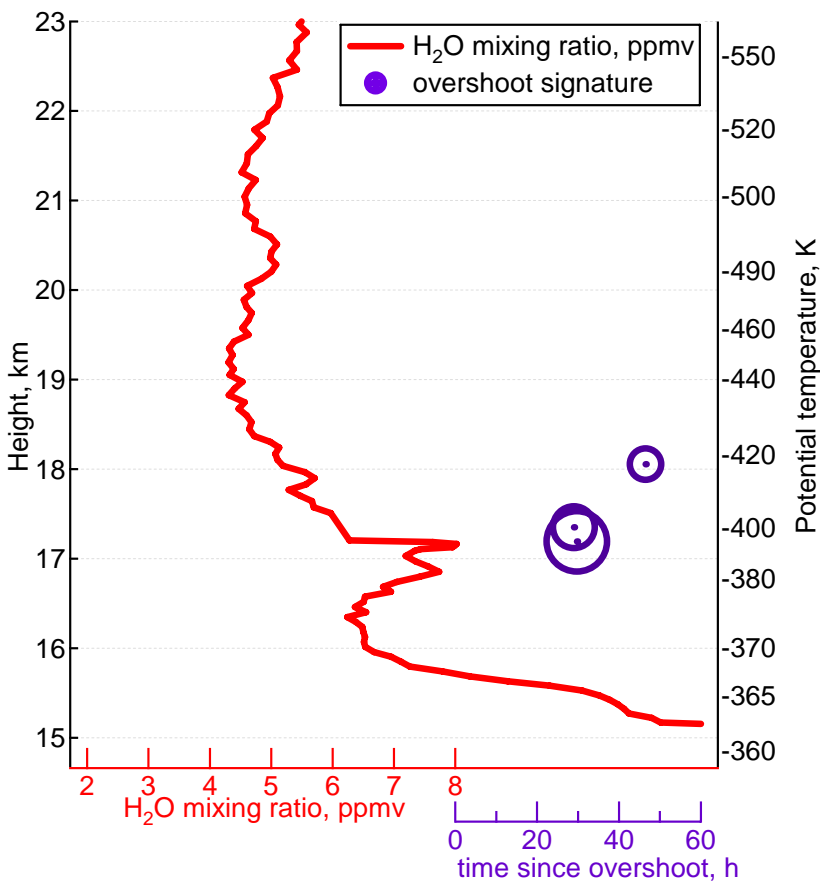

Fig. 4. Water vapour profile (solid red, bottom axis) above Niamey on 5 August 2006. Violet markers plotted against a secondary bottom axis are showing the altitude and the elapsed time since an overshoot was encountered upwind on the backward trajectories, identified in MSG images by the BTD technique (see text). The markers are size-coded with respect to the number of MSG overshooting pixels within a trajectory point domain.

on 14 August at $416 \mathrm{~K}$. Note that only $5 \%$ of the trajectories with overshoot signatures detected along their path, ending between the local CPT and $440 \mathrm{~K}$ level had no correspondence to enhanced water vapour layers.

A more complex case is that of 23 August showing coincident water vapour and particles layers for which upwind overshootings are reported $19-23 \mathrm{~h}$ before but also local thunderstorms seen by the radar next to the sounding. Ignoring this case and the 5 August bump at $492 \mathrm{~K}$, it is worth noting that all upwind overshoots occurred between 16:00 $\mathrm{h}$ local in the afternoon and 04:00 $\mathrm{h}$ in the night but with no marked preferred time and that the amplitude of the water vapour enhancement correlates roughly linearly with the number of MSG pixels, that is the size of the overshooting area.

A crude estimate of the vertical velocity near the cloud top required for explaining the altitude of the overshoot can be obtained by applying the rule of thumb proposed by Vonnegut and Moore (1958). Assuming that the lower stratosphere is isothermal and that the overshooting parcel ascent is adiabatic, these authors have indeed shown that one needs a vertical velocity of the order of $20 \mathrm{~m} / \mathrm{s}$ for every $1 \mathrm{~km}$ overshoot above the equilibrium level. Assuming an equilibrium level around $14 \mathrm{~km}$ as generally accepted for deep convection, the velocity required for explaining overshooting up to the altitude of the water vapour layers would be in the range $50-70 \mathrm{~m} / \mathrm{s}$, except for the case of the event at $492 \mathrm{~K}$ on 5 August, where an extreme velocity of $120 \mathrm{~m} / \mathrm{s}$ would be required. Although very large, updraughts of $50-70 \mathrm{~m} / \mathrm{s}$ are common in recent Cloud Resolving Models calculations as well as estimates from observations of extreme events (Mullendore et al., 2005; Grovesnor et al., 2007; Chaboureau et al., 2007 and references therein).

The first unexplained event is that at $492 \mathrm{~K}$ on 5 August, which would require an extreme velocity of the order of $120 \mathrm{~m} / \mathrm{s}$, substantially larger than all estimates and CRM simulations. This event for which no overshoot could be identified is thought to have another origin. Indeed on that day, the volcanic sulphate aerosol profile reported by the BKS sonde (Fig. 1) shows a peak at the same altitude, not seen on the other days, suggesting additional water from the sulphate aerosols.

For the other layer at lower altitude on 14 August for which no overshoot was identified within 3 days prior to the measurements and where volcanic aerosols are absent, a possible explanation could be the occurrence of overshootings more than 3 days earlier above Ethiopia, Somalia or Yemen, where very intense convection is present in the summer but off the $40^{\circ} \mathrm{E}$ limit of the MSG images.

An alternative mechanism explored for explaining the observed water vapour variability in the TTL is the exchange with mid-latitude shown by Borchi et al. (2007) to be responsible for $60-70 \%$ of ozone variability between $10-20^{\circ} \mathrm{S}$ during the summer season. Indeed, since the water vapour concentration around $390-420 \mathrm{~K}$ at mid-latitude is of the order of 4-4.5 ppmv (Gross and Russel III, 2005), an advection from there would result in a drier layer compared to the mean water vapour profile shown in Fig. 2. However, PV maps at $385 \mathrm{~K}$ and $435 \mathrm{~K}$ calculated by the MIMOSA contour advection model available at on the ETHER data base (http://ether.ipsl.jussieu.fr) show little indication of Rossby wave in the lower stratosphere in August 2006 but instead almost zonal isolines between Africa and the West Pacific shifting slowly back and forth in latitude with limited PV variations over Niamey (maximum $+8 \%$ anomaly compared to the mean at $435 \mathrm{~K}$ on 1-4 August and 21-27 August, $-8 \%$ on 14-19 August and nothing on 7 August). This absence of fresh import from mid-latitude during the period is confirmed by 10-days backward trajectories ending at the location of the balloon flights calculated from ECMWF analysis fields (M. Streibel, personal communication, 2008) showing almost zonal transport from the West Pacific during the whole month of August, without indication of transport from the mid-latitude at any level above $350 \mathrm{~K}$. Moreover, an ozonewater vapour scatter plot do not show any sign of correlation or anti-correlation between ozone and water vapour changes. For example, there is no difference in ozone $(<0.05 \mathrm{ppmv})$ between 16 and $20 \mathrm{~km}$ between the days of minimum ( $3 \mathrm{Au}$ gust) and maximum (14 August) water vapour. 
Table 2. Summary of observed water vapour enhanced layers and correlated convective overshoots upwind. From left to right: date of sounding, altitude and potential temperature of the layer, amplitude of enhancement compared to background, thickness of the layer in altitude and potential temperature units, delay between overshoot and sounding, local time of overshoot and size in MSG pixels.

\begin{tabular}{rcclllc}
\hline Date & $\begin{array}{c}\mathrm{H}_{2} \mathrm{O} \text { layer } \\
\text { altitude }(\mathrm{km}) \\
\text { pot. temp. }(\mathrm{K})\end{array}$ & $\begin{array}{c}\mathrm{H}_{2} \mathrm{O} \\
\text { enhancement } \\
(\mathrm{ppmv})\end{array}$ & $\begin{array}{l}\text { Layer } \\
\text { thickness } \\
(\mathrm{km} / \mathrm{K})\end{array}$ & $\begin{array}{l}\text { Time since } \\
\text { overshoot } \\
(\mathrm{h})\end{array}$ & $\begin{array}{l}\text { Local time } \\
\text { of overshoot } \\
(\mathrm{h})\end{array}$ & $\begin{array}{c}\text { Size of } \\
\text { overshoot } \\
\text { (pixels) }\end{array}$ \\
\hline 5 Aug & $17.1 / 391$ & 1.5 & $1.2 / 30$ & 30 & $15: 15$ & $23+12$ \\
$5 \mathrm{Aug}$ & $17.9 / 411$ & 0.6 & $0.6 / 9$ & 47 & $23: 30$ & 6 \\
$5 \mathrm{Aug}$ & $20.3 / 492$ & 0.6 & $1 / 16$ & $\mathrm{n} / \mathrm{a}$ & $\mathrm{n} / \mathrm{a}$ & $\mathrm{n} / \mathrm{a}$ \\
$14 \mathrm{Aug}$ & $17.0 / 384$ & 1.0 & $1.1 / 33$ & 44 & $03: 00$ & 33 \\
$14 \mathrm{Aug}$ & $18.2 / 416$ & 0.7 & $0.7 / 19$ & $\mathrm{n} / \mathrm{a}$ & $\mathrm{n} / \mathrm{a}$ & $\mathrm{n} / \mathrm{a}$ \\
$21 \mathrm{Aug}$ & $16.6 / 378$ & 0.8 & $0.3 / 11$ & 5 & $19: 00$ & $11+12$ \\
$21 \mathrm{Aug}$ & $17.2 / 408$ & 1.0 & $0.7 / 24$ & 6 & $18: 00$ & $7+3$ \\
$23 \mathrm{Aug}$ & $16.1 / 368$ & 7.0 & $1.2 / 21$ & 19,23 & $03: 00,23: 00$ & $7+7+6$ \\
$23 \mathrm{Aug}$ & $17.6 / 392$ & 1.1 & $0.3 / 5$ & 22 & $00: 00$ & 5 \\
$23 \mathrm{Aug}$ & $18.3 / 420$ & 0.5 & $0.3 / 9$ & 19 & $03: 00$ & 80 \\
\hline
\end{tabular}

In summary, unambiguous connection between enhanced water vapour layers reported by the sondes above the tropopause over Niamey and earlier upwind overshoots could be found in $80 \%$ of all the cases, for which no indication of alternative explanation such as advection from mid-latitudes could be identified. This conclusion is consistent with the idea of a hydration process of the lower stratosphere by fast uplift of water condensates across the tropopause over land areas. Although total water increases or ice crystals attributed to this process have been already observed over a number of tropical land areas during the convective season (Kley et al., 1982; Kelly et al., 1993; Nielsen et al., 2007; Chaboureau et al., 2007; Corti et al., 2008; De Reus et al., 2008), they seem to be particularly abundant in West Africa during the monsoon season, where high overshoot frequency, higher than anywhere else during that season, are reported by the TRMM PR radar (Liu and Zipser, 2005; Zipser et al., 2006).

\subsection{Ice particles and water vapour over a local convective system on 23 August 2006}

The next step is to understand how water amounts larger than those permitted by condensation at the temperature of the tropopause could penetrate the stratosphere. Three out of six profiles (14, 21 and particularly 23 August) show the presence of thin layers of particles above the CPT similar to that reported above the tropopause over Brazil and Northern Australia and simultaneous water vapour enhanced layers. Among these, the largest are observed on 23 August. An enlargement of the latter is shown in Fig. 5. The plot also includes the ascent ozone profile since the descent rate exceeding $20 \mathrm{~m} / \mathrm{s}$ in the stratosphere is too fast compared to $50 \mathrm{~s}$ time constant of the ECC sonde to provide useful information. Because of this time constant, the data recorded during the ascent at 5-6 m/s have been shifted downward by $250 \mathrm{~m}$ (Borchi et al., 2005).

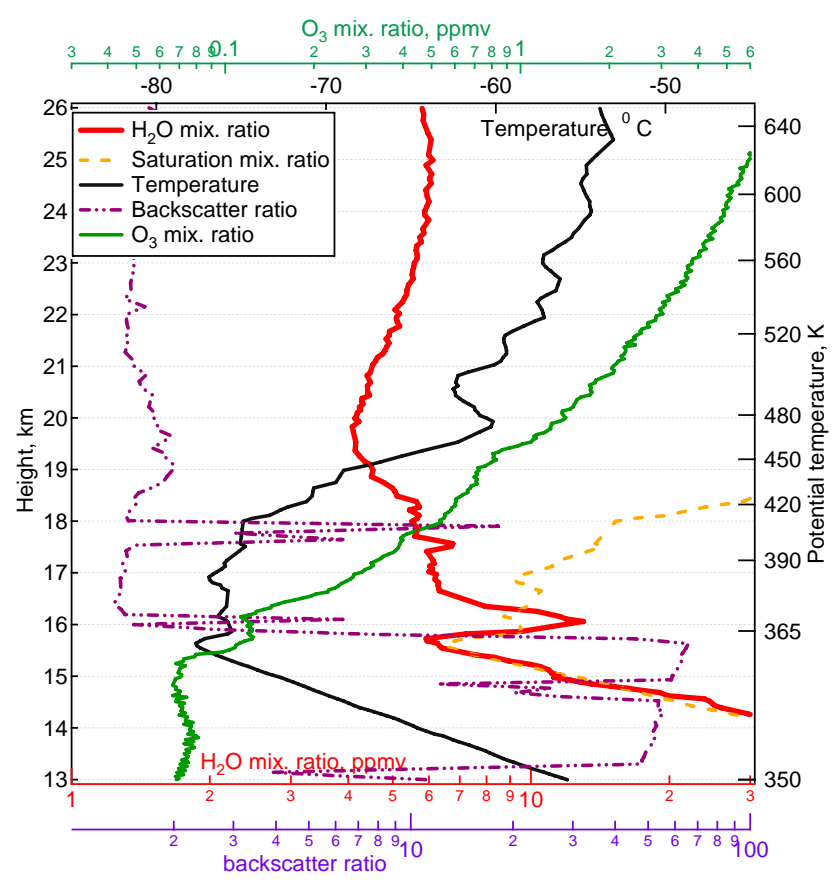

Fig. 5. Water vapour (solid red), RS-92 temperature (solid black), saturation mixing ratio (dotted magenta), and backscatter ratio at $940 \mathrm{~nm}$ (dash-dotted violet) during the descent of the sonde and ozone mixing ratio during ascent (solid green) on 23 August 2006.

Apart from the existence of upwind overshoots 19:0023:00 $\mathrm{h}$ before shown in Table 2, the specificity of this sounding in contrast to all others is that it was launched on a day of active local convection including a large MCS on the East 10:00 h upwind. The closest from the sonde descent, where particles were observed at $18 \mathrm{~km}$ altitude at 20:45 was a storm starting developing near Niamey around 19:15 for reaching a maximum between 20:00-20:30, whose anvil was observed by the BKS on both the ascent and the descent. 


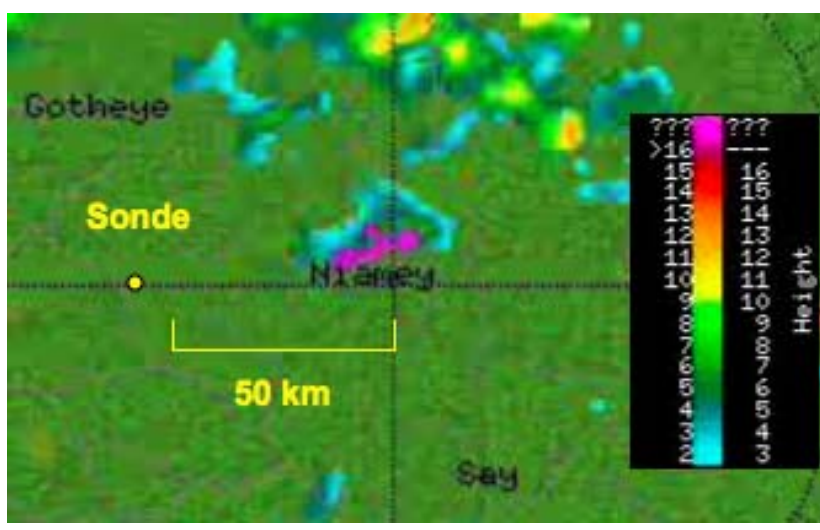

Fig. 6. Enlargement of MIT C-band radar cloud top height image at 20:31 UT on 23 August. Displayed are a squall line orientated NW-SE $50 \mathrm{~km}$ north of Niamey and a cell of $15 \mathrm{~km}$ width with area of reflectivity values higher than $40 \mathrm{dBZ}$ overhead Niamey on the northern edge of the silent zone of the radar. Since very close, the altitude extension of the storm is uncertain, the closest reliable data being the indication of cloud top at $13 \mathrm{~km}$ at the edge of the blind area at 20:09. Lightning was reported directly overhead at modest flash rate (a few per minute) without precipitation. The particle layer detected by the BKS at 20:45 at $18 \mathrm{~km}$ altitude was observed during the descent of the sonde $58 \mathrm{~km}$ west of the radar (yellow dot). The $76 \mathrm{~km} / \mathrm{h}, 88^{\circ}$ horizontal wind at this level would be compatible with the observation of material injected by that storm at $18 \mathrm{~km} \mathrm{30}$ $60 \mathrm{~min}$ before.

Shown in Fig. 6 is the cloud top radar image of that storm at 20:31 displaying a cell of $15 \mathrm{~km}$ width almost overhead Niamey, and the location of the sonde at $20: 45,58 \mathrm{~km}$ on the west. Since the storm developed close to the "silent cone" of the radar of 7-8 km radius at $15 \mathrm{~km}$ altitude where no data are available, the vertical extent of the MCS is uncertain. The most precise information available is the indication of a surge reaching $13 \mathrm{~km}$ at the edge of the silent cone at 20:09. Given the $76 \mathrm{~km} / \mathrm{h}$ wind from $88^{\circ}$ measured by the sonde at $18 \mathrm{~km}$, the particles would be compatible with an overshoot occurring $0.5-1 \mathrm{~h}$ before, depending on which part of the storm it has occurred. Within this delay, the sublimation lifetime of ice crystals and their sedimentation rate would imply overshooting particles of radii about $20 \mu \mathrm{m}$. These observations are very comparable to those of the FSSP-100 onboard the Geophysica high altitude aircraft in Northern Australia in November 2005, reporting particles of 12-25 $\mu \mathrm{m}$ effective radius above from the deep convective Hector system formed only half an hour prior to the observations (Corti et al., 2008; de Reus et al., 2008).

Most remarkable features of this event, which could be seen in Fig. 5 are: i) the unusually low altitude of the cold point tropopause at $15.6 \mathrm{~km}$ compared to the $16.4 \mathrm{~km}$ average and the extension of the cold layer up to $18 \mathrm{~km}$, which might be an indication of an injection of adiabatically cooled air over the local convective system resulting in the lower- ing of the CPT as shown by Pommereau and Held (2007); ii) ice saturation in a cloud anvil from $13-16 \mathrm{~km}$ saturating the BKS signal; iii) a relative minimum of water vapour at the cold point tropopause at $-78^{\circ} \mathrm{C}$ at $15.6 \mathrm{~km}$ corresponding to saturation; iv) the presence of a strongly supersaturated $(138 \% \mathrm{RHi})$ sharp water vapour peak immediately above the CPT at $16.2 \mathrm{~km}$, also present in the ascent profile (not shown) and thus not an instrumental artefact, coincident with a layer of ice crystals with radii in the range $0.5-10 \mu \mathrm{m}$ according to the BKS colour index (Nielsen et al., 2007); and v) the presence of small water vapour enhanced layers up to $18.5 \mathrm{~km}$ in a subsaturated region coincident with layers of ice crystals suggesting sublimation of the latter. Finally, remarkable also is the presence of dips in the ozone profile at $16.2 \mathrm{~km}$ and $17.8 \mathrm{~km}$ coincident with the water vapour and ice crystals layers, which could indicate an injection of respectively $20 \%$ and $3 \%$ ozone-poor tropospheric air mixing with stratospheric air (Nielsen et al., 2007).

Overall, the 23 August observations provide experimental evidence of stratosphere hydration by ice crystals freshly injected by overshooting turrets, a geyser-like feature, such as shown by pictures of severe storms taken from a Learjet (Fujita, 1992), now successfully captured by cloud resolving models.

\section{Concluding remarks}

A series of six balloon flights combining a fast response FLASH-B Lyman-alpha hygrometer and particles and ozone measurements supported by C-band ground-based radar observations has been carried out in West Africa during the monsoon season. The high vertical resolution observations show evidence of the presence of local accumulations of water vapour enhanced layers between the tropopause at $370 \mathrm{~K}$ $(16.5 \mathrm{~km})$ and the $420 \mathrm{~K}$ level $(18.3 \mathrm{~km})$. Most of them are shown connected with overshooting events upwind identified from satellite IR images by the brightness temperature difference technique, flown over by the air mass probed by the sondes along three days backward trajectories. In the case of local overshoots above the tropopause identified by echo tops turrets in the $\mathrm{C}$-band radar images, tight coincidence was found between enhanced water vapour, ice crystal and ozone dip layers indicative of fast uplift of tropospheric air across the tropopause. The water vapour mixing ratio in the enriched layers, higher than that of saturation at the tropopause, and the coincidence with the presence of ice crystals is consistent with a hydration process of the lower stratosphere by geyser-like injection of ice particles over overshooting turrets as captured by CRM models. The moisture increase at all levels up to $19 \mathrm{~km}$ in August in phase with the seasonal maximum temperature of the tropopause implies a process of fast uplift of water across the whole TTL. The coincidence of the event with the beginning of the convective season over an area known from the TRMM radar as the most important 
region of overshooting, suggests that such hydration mechanism may contribute to the known water vapour summer maximum in the lower stratosphere.

Acknowledgements. The authors thank the CNES balloon team, the West African ASECNA, the Niger Air Traffic Control, Air Force, and National Meteorological Direction (DMN), the French Institute for Research and Development (IRD) in Niamey and the AMMA project, particularly A. Diedhou and C. Kane of the AMMA Operation Center for their help in sondes operations and K. Ramage of the ClimServ data base for his help in the use of MSG images, which are all gratefully acknowledged. This work was supported by the EC SCOUT-O3 integrated project (505390GOCE-CT-2004), INSU in France, the INTAS YSF 05-109-4955 grant, the ISTC \#3093 project and RFBR \#07-05-00486 grant in Russia. The authors thank also the referees and the editor for their many useful comments.

Edited by: D. Brunner

\section{References}

Bertaux, J. L. and Delannoy, A.: Premieres mesures stratosphériques par un hygromètre a fluorescence ultraviolette, Cr. Acad. Sci. Paris, 286, 191-194, 1978.

Borchi, F., Pommereau, J.-P., Garnier, A., and Pinharanda, M.: Evaluation of SHADOZ sondes, HALOE and SAGE II ozone profiles at the tropics from SAOZ UV-Vis remote measurements onboard long duration balloons, Atmos. Chem. Phys., 5, 13811397, 2005, http://www.atmos-chem-phys.net/5/1381/2005/.

Brewer, A. W.: Evidence for a world circulation provided by the measurements of helium and water vapour distribution in the stratosphere, Q. J. Roy. Meteor. Soc., 75, 351-363, 1949.

Chaboureau, J.-P., Cammas, J.-P., Duron, J., Mascart, P. J., Sitnikov, N. M., and Voessing, H.-J.: A numerical study of tropical crosstropopause transport by convective overshoots, Atmos. Chem. Phys., 7, 1731-1740, 2007, http://www.atmos-chem-phys.net/7/1731/2007/.

Corti, T., Luo, B. P., de Reus, M., Brunner, D., Cairo, F., Mahoney, M. J., Martucci, G., Matthey, R., Mitev, V., dos Santos, F. H., Schiller, C., Shur, G., Sitnikov, N. M., Spelten, N., Vossing, H. J., Borrmann, S., and Peter, T.: Unprecedented evidence for overshooting convection hydrating the tropical stratosphere, Geophys. Res. Lett., 35, L10810, doi:10.1029/2008GL033641, 2008.

Danielsen, E. F.: A dehydration mechanism for the stratosphere, Geophys. Res. Lett., 9, 605-608, 1982.

Danielsen, E. F.: Insitu evidence of rapid, vertical, irreversible transport of lower tropospheric air into the lower tropical stratosphere by convective cloud turrets and by larger-scale upwelling in tropical cyclones, J. Geophys. Res.-Atmos., 98 , 8665$8681,1993$.

de Reus, M., Borrmann, S., Heymsfield, A. J., Weigel, R., Schiller, C., Mitev, V., Frey, W., Kunkel, D., Kürten, A., Curtius, J., Sitnikov, N. M., Ulanovsky, A., and Ravegnani, F.: Evidence for ice particles in the tropical stratosphere from in-situ measurements, Atmos. Chem. Phys. Discuss., 8, 19313-19355, 2008, http://www.atmos-chem-phys-discuss.net/8/19313/2008/.
Durry, G., Huret, N., Hauchecorne, A., Marecal, V., Pommereau, J.-P., Jones, R. L., Held, G., Larsen, N., and Renard, J.-B.: Isentropic advection and convective lifting of water vapor in the UT - LS as observed over Brazil $\left(22^{\circ} \mathrm{S}\right)$ in February 2004 by in situ high-resolution measurements of $\mathrm{H}_{2} \mathrm{O}, \mathrm{CH}_{4}, \mathrm{O}_{3}$ and temperature, Atmos. Chem. Phys. Discuss., 6, 12469-12501, 2006, http://www.atmos-chem-phys-discuss.net/6/12469/2006/.

Forster, P. M. and Shine, K. P.: Assessing the climate impact of trends in stratospheric water vapor, Geophys. Res. Lett., 29, 1086, doi:10.1029/2001GL013909, 2002.

Fujita, T. T.: Teton-Yellowstone tornado of 21 July 1987, Mon. Weather Rev., 117, 1913-1940, 1989.

Fujita, T. T.: Mystery of Severe Storms, during the 50 years 1942 1992, Wind Research Laboratory, Department of Geophysical Sciences, University of Chicago, 1992.

Grooß, J.-U. and Russell III, James M.: Technical note: A stratospheric climatology for $\mathrm{O}_{3}, \mathrm{H}_{2} \mathrm{O}, \mathrm{CH}_{4}, \mathrm{NO}_{\mathrm{x}}, \mathrm{HCl}$ and $\mathrm{HF}$ derived from HALOE measurements, Atmos. Chem. Phys., 5, 2797-2807, 2005, http://www.atmos-chem-phys.net/5/2797/2005/.

Grosvenor, D. P., Choularton, T. W., Coe, H., and Held, G.: A study of the effect of overshooting deep convection on the water content of the TTL and lower stratosphere from Cloud Resolving Model simulations, Atmos. Chem. Phys., 7, 4977-5002, 2007, http://www.atmos-chem-phys.net/7/4977/2007/.

Hanisco, T. F., Moyer, E. J., Weinstock, E. M., St. Clair, J. M., Sayres, D. S., Smith, J. B., Lockwood, R., Anderson, J. G., Dessler, A. E., Keutsch, F. N., Spackman, J. R., Read, W. G., and Bui, T. P.: Observations of deep convective influence on stratospheric water vapor and its isotopic composition, Geophys. Res. Lett., 34, L04814, doi:10.1029/2006GL027899, 2007.

Holton, J. R., Haynes, P. H., McIntyre, M. E., Douglass, A. R., Rood, R. B., and Pfister, L.: Stratosphere-troposphere exchange, Rev. Geophys., 33, 403-439, 1995.

Jensen, E. J., Smith, J. B., Pfister, L., Pittman, J. V., Weinstock, E. M., Sayres, D. S., Herman, R. L., Troy, R. F., Rosenlof, K., Thompson, T. L., Fridlind, A. M., Hudson, P. K., Cziczo, D. J., Heymsfield, A. J., Schmitt, C., and Wilson, J. C.: Ice supersaturations exceeding $100 \%$ at the cold tropical tropopause: implications for cirrus formation and dehydration, Atmos. Chem. Phys., 5, 851-862, 2005, http://www.atmos-chem-phys.net/5/851/2005/.

Kelly, K. K., Proffitt, M. H., Chan, K. R., Loewenstein, M., Podolske, J. R., Strahan, S. E, Wilson, J. C., and Kley, D.: Water vapor and cloud water measurements over Darwin during the STEO 1987 tropical mission, J. Geophys. Res., 98(D5), 87138723, 1993.

Kent, G. S, Williams, E. R. Wang, P. H., McCormick, M. P., and Skeens, K. M.: Surface temperature-related variations in tropical cirrus clouds as measured by SAGE II, J. Climate, 8, 2577-2594, 1995.

Khaplanov, M., Astakhov, V., Lukjanov, A., Kretova, M., and Yushkov, V.: Fluorescent hygrometer for middle atmosphere measurements, Proc. 19th Annual European Meeting on Atmospheric Studies by Optical Methods, 540-545, 1992.

Khaykin, S., Pommereau, J. P., Vömel, H., Korshunov, L., Yushkov, V., and Nielsen, J.: Water vapour in the tropical UT/LS from balloon observations with FLASH-B hygrometer, Geophys. Res. Abstracts, 10, EGU2008-A-00444, 2008. 
Kley, D. and Stone, E. J.: Measurements of water vapor in the stratosphere by photodissotiation with Ly-alpha (1216A) light, Rev. Sci. Instrum., 49, 661-697, 1978.

Kley, D., Schmeltkopf, A. L., Kelly, K., Winkler, R. H., Thompson, T. L., and McFarland, M.: Transport of water vapor through the tropical tropopause, Geophys. Res. Lett., 9, 617-620, 1982.

Liu, C. and Zipser, E. J.: Global distribution of convection penetrating the tropical tropopause, J. Geophys. Res. , 110, D23104, doi:10.1029/2005JD006063, 2005.

Lukyanov, A., Nakane, H., and Yushkov, V.: Lagrangian estimations of ozone loss in the core and edge region of the arctic polar vortex 1995/1996: Model results and observations, J. Atmos. Chem., 44(2), 191-210, 2003.

Mathon, V., Laurent, H., and Lebel, T. Mesoscale convective systems in the Sahel, J. Appl. Meteorol., 41(11), 1081-1092, 2002.

Montoux, N., Hauchecorne, A., Pommereau, J.-P., Durry, G., Morel, B., Jones, R. L., Lefèvre, F., and Bencherif, H.: Evaluation of balloon and satellite water vapour measurements in the Southern tropical UTLS during the HIBISCUS campaign, Atmos. Chem. Phys. Discuss., 7, 6037-6075, 2007,

http://www.atmos-chem-phys-discuss.net/7/6037/2007/.

Mote, P. W., Rosenlof, K. H., Mclntyre, M. E., Carr, E. S., Gille, J. C., Holton, J. R., Kinnersley, J. S., Pumphrey, H. C., Russell III, J. M., and Waters, J. W.: An atmospheric tape recorder: The imprint of tropical tropopause temperatures on stratospheric water vapor, J. Geophys. Res., 101, 3989-4006, 1996.

Nielsen, J. K., Larsen, N., Cairo, F., Di Donfrancesco, G., Rosen, J. M., Durry, G., Held, G., and Pommereau, J. P.: Solid particles in the tropical lowest stratosphere, Atmos. Chem. Phys., 7, 685695, 2007, http://www.atmos-chem-phys.net/7/685/2007/.

Oltmans, S., Vömel, H., Hofmann, D., Rosenlof, K., and Kley, D.: The increase in stratospheric water vapor from balloon-borne, frostpoint hygrometer measurements at Washington, D.C. and Boulder, Colorado, Geophys. Res. Lett., 27(21), 3453-3456, 2000.

Pommereau, J.-P. and Held, G.: Is there a stratospheric fountain?, Atmos. Chem. Phys. Discuss., 7, 8933-8950, 2007, http://www.atmos-chem-phys-discuss.net/7/8933/2007/.

Pommereau, J.-P., Garnier, A., Held, G., Gomes, A.-M., Goutail, F., Durry, G., Borchi, F., Hauchecorne, A., Montoux, N., Cocquerez, P., Letrenne, G., Vial, F., Hertzog, A., Legras, B., Pisso, I., Pyle, J. A., Harris, N. R. P., Jones, R. L., Robinson, A., Hansford, G., Eden, L., Gardiner, T., Swann, N., Knudsen, B., Larsen, N., Nielsen, J., Christensen, T., Cairo, F., Pirre, M., Marécal, V., Huret, N., Riviére, E., Coe, H., Grosvenor, D., Edvarsen, K., Di Donfrancesco, G., Ricaud, P., Berthelier, J.-J., Godefroy, M., Seran, E., Longo, K., and Freitas, S.: An overview of the HIBISCUS campaign, Atmos. Chem. Phys. Discuss., 7, 2389-2475, 2007, http://www.atmos-chem-phys-discuss.net/7/2389/2007/.

Randel, W. J., Wu, F., Vömel, H., Nedoluha, G. E., and Forster, P.: Decreases in stratospheric water vapor after 2001: Links to changes in the tropical tropopause and the Brewer-Dobson circulation, J. Geophys. Res., 111, D12312, doi:10.1029/2005JD006744, 2006.

Ricaud, P., Barret, B., Attié, J.-L., Motte, E., Le Flochmoën, E., Teyssèdre, H., Peuch, V.-H., Livesey, N., Lambert, A., and Pommereau, J.-P.: Impact of land convection on tropospherestratosphere exchange in the tropics, Atmos. Chem. Phys., 7, 5639-5657, 2007, http://www.atmos-chem-phys.net/7/5639/2007/.

Richard, E. C., Tuck, A. F., Aikin, C., Kelly, K. K., Herman, R. L., Troy, R. F., Hovde, S. J., Rosenlof, K. H., Thompson, T. L., and Ray, A.: High-resolution airborne profiles of $\mathrm{CH}_{4}$, $\mathrm{O}_{3}$, and water vapour near tropical Central America in late January to early February 2004, J. Geophys. Res., 111, D13304, doi:10:1029/2005JD006513, 2006.

Rosen, J. M. and Kjome, N. T.: Backscattersonde - A new instrument for atmospheric aerosol research, Appl. Optics, 30, 15521561, 1991.

Rosenlof, K., Oltmans, S., Kley, D., Russell III, J. M., et al.: Stratospheric water vapor increases over the past half-century, Geophys. Res. Lett., 28(7), 1195-1198, 2001.

Schmetz, J., Tjemkes, S. A., Gube, M., and van de Berg, L.: Monitoring deep convection and convective overshooting with METEOSAT, Adv. Space Res., 19, 433-441, 1997.

Sherwood, S. C. and Dessler, A. E.: On the control of stratospheric humidity, Geophys. Res. Lett., 27, 2513-2516, 2000.

Schiller, C., Brunner, D., Konopka, P., Kraemer, M., Shur, G., Silva Dos Santos, F., Sitnikov, N., and Spelten, N.: Water and Relative Humidity at the Tropical Tropopause, American Geophysical Union, Fall Meeting 2007, \#A21E-0771, 2007.

Schiller, C., Krämer, M., Afchine, A., Spelten, N., and Sitnikov, N.: Ice water content in Arctic, mid latitude and tropical cirrus, J. Geophys. Res., 113, D24208, doi:10.1029/2008JD010342, 2008.

Seidel, D. J., Ross, R. J., Angell, J. K., and Reid, G. C.: Climatological characteristics of the tropical tropopause as revealed by redionsondes, J. Geophys. Res., 106(D8), 7857-7878, 2001.

Solomon, S., Garcia, R. R., Rowland, F. S., and Wuebbles, D. J.: On the depletion of Antarctic ozone, Nature, 321, 755-758, 1986.

Tuck, A., Hovde, S. J., Kelly, K. K., Reid, S. J., Richard, E. C., Atlas, E. L., Donnelly, S. G., Stroud, V. R., Cziczo, D. J., Murphy, D. M., Thomson, D. S., Elkins, J. W., Moore, F. L., Ray, E. A., Mahoney, M. J., and Friedl, R. R.: Horizontal variability 1-2 km below the tropical tropopause, J. Geophys. Res., 109, D05310, doi:10.1029/2003JD003942, 2004.

Vaughan, G., Schiller, C., MacKenzie, A. R., Bower, K., Peter, T., Schlager, H., Harris, N. R. P., and May, P. T.: SCOUTO3/ACTIVE: High-altitude Aircraft Measurements around Deep Tropical Convection, B. Am. Meteorol. Soc., 89, 647-662, 2008.

Vernier, J.-P., Pommereau, J. P., Garnier, A., Cairo, F., Di Donfrancesco, G., Mercer, J., Deshler, T., Nielsen, J., Christensen, T., Larsen, N., and Capes, G.: Volcanic aerosols as tracers in the TTL, Proc. Reunion Island Internat. Symp., November 2007.

Vömel, H., Oltmans, S. J., Johnson, B. J., Hasebe, F., Shiotani, M., Fujiwara, M., Nishi, N., Agama, M., Cornejo, J., Paredes, F., and Enriquez, H.: Balloon-borne observations of water vapour and ozone in the tropical upper troposphere and lower stratosphere, J. Geophys. Res., 107(D14), 4210-4222, 2002.

Vömel, H., Yushkov, V., Khaykin, S., Korshunov, L., Kyrö, E., and Kivi, R.: Intercomparisons of Stratospheric Water Vapor Sensors: FLASH-B and NOAA/CMDL Frost-Point Hygrometer, J. Atmos. Ocean. Tech., 24, 941-952, 2007.

Vonnegut, B. and Moore, C. B.: Giant Electrical storms, Recent Advances in Atmospheric Electricity, Pergamon Press (London), 399-411, 1958.

Wang, P. K.: A cloud model interpretation of jumping cirrus above storm top, Geophys. Res. Lett., 31, L18106, doi:10.1029/2004GL020787, 2004. 
Weinstock, E. M., Hintsa, E. J., Dessler, A. E., and Anderson, J. G.: Measurements of water vapour in the tropical lower stratosphere during CEPEX campaign: Results and interpretation, Geophys. Res. Lett., 22(23), 3231-3234, 1995.

Williams, E., Nathou, N., Hicks, E., Pontikis, C., Russell, B., Miller, M., and Bartholomew, M. J.: The Electrification of DustLofting Gust Fronts ("Haboobs") in the Sahel, Atmos. Res., 91(2-4), 292-298, doi:10.1016/j.atmosres.2008.05.017, 2009.

WMO: Scientific assessment of Ozone Depletion: 2006. Global Ozone Research and Monitoring project, Report No. 50, 572 pp., Geneva, 2007.

Yushkov, V., Merkulov, S., and Astakhov, V.: Optical balloon hygrometer for upper stratosphere and stratosphere water vapour measurements, in: Optical remote sensing of the atmosphere and clouds, edited by: Wang, J., Wu, B., Ogawa, T., and Guans, Z.H.: Proc. SPIE, 3501, 439-445, 1998.
Yushkov, V., Sitnikov, N., Zaitcev, I., Pommereau, J.-P., and Garnier, A.: Stratospheric water vapor measurements in the winter arctic with optical fluorescence hygrometer on short and long duration balloons, in: Proceedings of the 15th ESA Symposium on European Rocket and Balloon programmes and Related Research, edited by: Warmbein, B., Biarritz, France, ESA SP-471, 28-31 May 2001, ESA, 263-268, 2001.

Zipser, E. J., Cecil, D. J., Liu, C., Nesbitt, S. W., and Yorty, D. P.: Where are the most intense thuderstroms on Earth?, B. Am. Meteorol. Soc., 1057-1071, 2006.

Zoger, M., Schiller, C., and Eicke, N.: Fast in situ hygrometers: A new family of balloon-borne and airborne Lyman-? photofragment fluorescence hygrometers, J. Geophys. Res., 104, 18071816, 1999. 